\title{
REPRESENTATION OF SELF-CONCEPT IN THE COLLECTION OF CHILDREN'S STORIES FROM BOBO MAGAZINE
}

\author{
Wita Siti Mahmudah ${ }^{1, *}$, Seni Apriliya ${ }^{2}$, Ahmad Mulyadiprana $^{3}$ \\ ${ }^{1}$ Primary Teacher Education Department, Faculty of Education, Universitas Pendidikan Indonesia, Jl. Dadaha \\ No. 18 Tasikmalaya City, Tasikmalaya 46115, Indonesia \\ ${ }^{2}$ Primary Teacher Education Department, Faculty of Education, Universitas Pendidikan Indonesia, Jl. Dadaha \\ No. 18 Tasikmalaya City, Tasikmalaya 46115, Indonesia \\ ${ }^{3}$ Primary Teacher Education Department, Faculty of Education, Universitas Pendidikan Indonesia, Jl. Dadaha \\ No. 18 Tasikmalaya City, Tasikmalaya 46115, Indonesia
}

\section{ARTICLE INFO}

Keywords:

Bobo Magazine

Children stories

Children's literature

Self-concept

Article History:

Received: 18/07/2021

Accepted: 18/11/2021

Available Online:

30/11/2021

\begin{abstract}
A B S T R A C T
As construction of thought, self-concept will continue to grow and develop following the life experiences, one of which can come from stories. Therefore, this study aims to uncover and describe indicators of self-concept from children's stories. The data was obtained based on ten children's stories from the online version of Bobo magazine published in 2019-2020. This research used the content analysis method with categorization and tabulation until inference was found. The results revealed that Bobo magazine had implied selfconcepts in the published stories. Among them, such as self-identity related to the labels attached by other characters as well as the character's desire to be what kind of self; personal behavior related to the views of other characters and figures in viewing their behavior; and self-judgment related to the acceptance or rejection of the character's behavior. Then, the physical selfconcept associated with gender and character skills; moral self-concept related to the character's ability to control his behavior; personal self-concept related to good relations between characters; family self-concept related to the character's relationship with his family members; and social self-concept related to the character's relationship with his peers. These findings appear to confirm the representation of self-concepts in Indonesian children's short stories.
\end{abstract}

2442-305X / (C) 2021 The Authors, this is open access article under the (CC-BY-NC) license (https://creativecommons.org/licenses/by-nc/4.0/), DOI:10.19105/ojbs.v15i2.4893

\footnotetext{
$\overline{* \text { Corresponding Author: }}$

Email address: witasitim@upi.edu (W. S. Mahmudah)
}

\section{A. Introduction}

The increasing number of magazines and newspapers that publish children's rubrics with various stories creates fresh reading material that will appeal to all readers. Essentially, everyone enjoys stories, particularly youngsters who are in the process of gaining, nurturing, and developing 
numerous life signs. ${ }^{1}$ However, in fact, children's stories in the field do not always directly express the child's self-concept. In reality, tales can help children grasp their own self-concept. Because the process of establishing morals and ethics in children's stories is transmitted through metaphors rather than directly. So that the learning process is enjoyable and does not come off as condescending.

Children's literature, in this case, children's stories, has the function and benefit of entertaining and educating children as readers. In addition, it can also be used as a medium and strategy to encourage children to interact and understand their social identity. ${ }^{2}$ Children's stories are also seen as an effective medium to form various values and ethics, even to instill self-concept.

The self-concept contained in the story is expected to be understood by children and can indirectly reconstruct their attitudes and personalities. Children are also expected to be able to more easily understand various attitudes through the role of the characters in the story so that in the story, the characters can become an illustration or role model for children in forming their self-concept.

\footnotetext{
1 Burhan Nurgiyantoro, "Sastra Anak: Persoalan Genre," Humaniora 16, no. 2 (2012): 107-22, https://doi.org/10.22146/jh.811.

2 Riris K. Toha Sarumpaet, Pedoman Penelitian Sastra Anak (Jakarta: Yayasan Pustaka Obor, 2010), 3; Seni Apriliya et al., "Social Identity in Indonesian Children's Literature: Materials of SelfLiteracy for Elementary Students" (3rd International Conference on Education, Sports, Arts and Management Engineering (ICESAME 2018), Atlantis Press, 2018), 548-50, https://doi.org/10.2991/amca-18.2018.152.
}

So far, literary studies on selfconcept in children's stories have not been found. However, there are several studies related to children's stories, including studies on the ideal moral personality of children ${ }^{3}$ and those related to character education. ${ }^{4}$ Whether exciting or not, the elements in a story can be subjective because they are related to aesthetics. However, values related to the child's self-concept, children's stories should present an explicit self-concept dimension that is able to reveal what the child's self-concept looks like. This is based on the fact that self-concept needs to be instilled from an early age by providing it in children's stories because through these stories, children will describe themselves as characters in stories. For this reason, the self-concept in children's stories must be studied and identified.

This study aims to reveal and describe indicators of self-concept depicted in children's stories from Bobo magazine which are published online on their official website. The choice of Bobo magazine is based on the fact that this magazine has been established since 1973, which means that for 48 years, this magazine still exists and of course has faced various generations to date. As a

\footnotetext{
${ }^{3}$ Heru kurniawan Kurniawan et al., "Kepribadian Moral Ideal Anak dalam Cerita Anak pada Majalah Bobo dan Harian Kompas," Lingua 14, no. 2 (2018): 226-40.

${ }^{4}$ Nurweni Saptawuryandari, "Cerita Pendek Anak dalam Majalah Bobo Tahun 1980-an Sebagai Bacaan Pendidikan Karakter," ATAVISME 17, no. 2 (2014): 254-63, https://doi.org/10.24257/atavisme.v17i2.14.254 263.
} 
basis for conducting this research, this research uses developmental psychology theory about self-concept and children's literature.

If sorted, self-concept has a long history as an idea before finally giving birth to a theory that is widely interpreted by experts. According to Bailey's view, "self-concept is more of an approach/estimate because it relates to the qualities that exist in a person, form, or principle." ${ }^{5}$ Several experts define selfconcept, including Hurlock, who calls this self-concept related to individual beliefs about who and what he is based on the views of important people in his life, so that it is like a mirror image which is largely determined by roles, relationships with other people, what he believes in, and how other people react to him. Selfconcept is also seen as the core of the picture of a person's personality development that affects various forms of a person's nature. ${ }^{6}$ Furthermore, Agustiani defines self-concept as a picture that a person has about himself, which is formed through experiences gained from interaction with the environment. ${ }^{7}$

Based on the three theories above, self-concept is simply interpreted as an individual's perspective in looking at himself, based on what is perceived, and desired towards himself which is also influenced by the perspective and

\footnotetext{
${ }^{5}$ Joseph A. Bailey, "Self-Image, Self-Concept, and Self-Identity Revisited.," Journal of the National Medical Association 95, no. 5 (2003): 383-86.

${ }^{6}$ Elizabeth Bergner Hurlock, Child Development, 5th ed. (New York: McGraw-Hill, 1978), 365.

7 Hendriati Agustiani, Psikologi Perkembangan (Bandung: PT. Refika Aditama, 2009), 138.
}

reactions of others towards him. In this study, the self-concept in question is all forms of views about the character's self that are expected or embedded by himself or other characters; it comes from the interactions and thoughts of the characters themselves.

And then, based on the research report conducted by W. H. Fitts with W. L. Warren believes that self-concept is an important indicator in a person because it serves as a frame of reference when interacting with the environment. ${ }^{8}$ Someone who has a positive self-concept will undoubtedly be an individual who views himself positively, feels optimistic and confident, dares to take risks, and is enthusiastic about setting the direction and goals of life. ${ }^{9}$ On the other hand, Fitts and Warren also divide self-concept into two dimensions, namely internal dimensions, and external dimensions. This internal dimension relates to self-identity, self-behavior, and self-judgment. ${ }^{10}$

Self-identity is a fundamental indicator of self-concept because it relates to the labels attached to the individual to build his identity. Getting older and having more interactions with the environment, the individual's knowledge about himself increases. So, they can complete information about themselves with more

\footnotetext{
${ }^{8}$ William H. Fitts and W. Louis Warren, Tennessee Self-Concept Scale, 2nd ed. (California: Western Psychological Services, 1996), 3.

9 Nirwana, "Konsep Diri, Pola Asuh Orang Tua Demokratis dan Kepercayaan Diri Siswa," Persona: Jurnal Psikologi Indonesia 2, no. 2 (2013): 153-61, https://doi.org/10.30996/persona.v2i2.103.

10 Fitts and Warren, Tennessee Self-Concept Scale, 3.
} 
complex things, for example, wanting to be "who." Self-behavior is related to the individual's perception of his behavior, in which there is an awareness of how he acts. Furthermore, self-judging is related to the acceptance or rejection of behavior and identity. Self-judging also determines a person's satisfaction with himself or how far others can accept it. The term refusal in the indicator of self-judging refers to a form of regret or ungratefulness for the consequences of one's actions. At the same time, the term acceptance refers to a sense of gratitude and appreciation for his actions.

While the external dimension is related to the individual's judgment through his social relationships and activities. The indicators related to the external dimensions of self-concept are divided into five, including: ${ }^{11}$

1) Physical self-concept, which measures a person's views related to health, appearance, physical skills, and gender.

2) Moral self-concept, which is related to a person's ability to control his own behavior.

3) Personal self-concept is linked to the ability to adapt and maintain positive relationships with others.

4) Family self-concept is related to a person's view of his existence in his family and relatives.

5) Social self-concept is a measure of a person's views related to his relationship with peers.
Meanwhile, children's stories are one of the genres of children's literature, ${ }^{12}$ especially realism stories that tell about social problems by showing the roles of the characters as actors in the story. The narrated problems can relate to oneself or others, which are realistic as often found in everyday life.

Children's stories are stories in which children are the subject that is the focus of attention. ${ }^{13}$ Furthermore, children's stories are literary works that represent childhood, even though it is written by adults. ${ }^{14}$ That is, children's stories are made based on the child's point of view written using simple language and can be understood by the child's thinking power, have an easy-tounderstand plot, simple character traits, and have a mandate that can convey positive moral messages, so that children feel entertained and happy, they can gain valuable knowledge. Children's stories can also tell you about anything, even if you think it does not make sense. In other words, children's stories can provide more information and understanding about life itself.

The children's story is a narrative story with various characters in it. The term character refers to the figure or actor

\footnotetext{
${ }^{12}$ Nurgiyantoro, "Sastra Anak," 13.

${ }^{13}$ Nurgiyantoro, 6.

${ }^{14}$ Wellington Amancio da Silva, "Literature Children - Child as Protagonist," International Journal of Elementary Education 3, no. 3 (2014): 54-57, https://doi.org/10.11648/j.ijeedu.20140303.11; Yenni Hayati, "The Use of Foreign Languages in Children Literature in Indonesia," Humanus 15, no. 2 (2016): 226-35, https://doi.org/10.24036/jh.v15i2.6511.
}

${ }^{11}$ Fitts and Warren, 2-3. 
told in the story. ${ }^{15}$ As a fictional element of a story, characters are used as representations of individuals in the real world so that they are relevant to be used as images in internalizing self-concept. Therefore, the social life described in children's stories is mostly centered on the family, school, and friendly environment. This happens because through the interaction between these people, children can understand their selfconcept, which is also related to the expected self-image.

The research of self-concept and its relation to children's stories has been widely carried out, for example, the research conducted by Elaine, who conducts research to determine literature's effect on the self-concept of Negro children. Moreover, the results show that children's literature that upholds Negro has a good affect. ${ }^{16}$ Aside from that, Tobias Richter et al., regarding the effect of stories on self-concept, especially on gender stereotypes. His research results show that there is growing evidence that mass-mediated stories can influence how we judge features of the outside world and how we perceive ourselves. ${ }^{17}$ Then, some studies include children's stories as data sources, for

15 Albertine Minderop, Psikologi Sastra: Karya Sastra, Metode, Teori, dan Contoh Kasus (Jakarta: Yayasan Pustaka Obor Indonesia, 2010), 61.

${ }^{16}$ Elaine H. Wagener, "Does Literature Affect SelfConcept?," Peabody Journal of Education 53, no. 4 (1976): 299-302 https://www.jstor.org/stable/1492283.

17 Tobias Richter, Markus Appel, and Frank Calio, "Stories Can Influence the Self-Concept," Social Influence 9, no. 3 (2014): 172-88, https://doi.org/10.1080/15534510.2013.799099. example, regarding the use of children's short stories as character education readings, ${ }^{18}$ and the effects of quality books for children to help increase children's self-esteem. ${ }^{19}$ Based on these studies, it can be seen that no research specifically covers the representation of self-concept in children's stories.

Therefore, this study will be further identified in the short story content published in Bobo magazine. Through Bobo magazine, the child's self-concept that will be identified only comes from the various relationships between the main character and other characters in the context of social life in family, school, and friendship. Thus, this study aims to uncover the picture of self-concept in children's stories from Bobo magazine; and describe the picture of the selfconcept of children's characters based on self-concept indicators.

\section{B. Method}

The focus of this study aimed to uncover and describe indicators of selfconcept described by children's stories. In line with these objectives, in line with these objectives, we used a qualitative approach with content analysis methods. The data collected was verbal data, consisting of quotations of words, phrases, paragraphs, or discourses in a

18 Saptawuryandari, "Cerita Pendek Anak dalam Majalah Bobo Tahun 1980-an sebagai Bacaan Pendidikan Karakter." 254-263.

19 Janina Uszyńska-Jarmoc, "The Conception of Self in Children's Narratives," Early Child Development and Care 174, no. 1 (2004): 81-97, https://doi.org/10.1080/0300443032000153507. 
predetermined set of texts. ${ }^{20}$ The selection of this method is based on the fact that the data collected is qualitative data in the form of quotations and not quantitative data containing numbers.

The data collection technique was carried out by reading repeatedly and then recording data related to self-concept indicators. The data processing technique was carried out with the stages of categorization and tabulation. Then the data was analyzed and interpreted according to the theory of self-concept according to Fitts to obtain inference. The object of this research material was ten children's stories (see Table 1) published by Bobo magazine from 2019 to 2020 online on their official website. This story was chosen based on the main characters' in stories, which are children.

The formal object of this research is the self-concept indicator in the Indonesian children's story. The instrument used to collect data in this study was a data card.

Table 1.

Titles and Authors of Bobo Magazine Children's Story Scripts

\begin{tabular}{lll}
\hline No. & Story Title & Author \\
\hline 1 & Circus & Lena D. \\
\hline 2 & $\begin{array}{l}\text { The } \\
\text { Disappointed } \\
\text { Little Author }\end{array}$ & \\
\hline
\end{tabular}

${ }^{20}$ Lexy J. Moleong, Metodologi Penelitian Kualitatif (Bandung: Remaja Rosdakarya, 2009), 11; Jeanne Shay Schumm et al., "A Content Analysis of College Reading Association/Association of Literacy Educators and Researchers Teacher Education Publications: Past, Present, and Future," Literacy Research and Instruction 53, no. 3 (2014): 225-44,

https://doi.org/10.1080/19388071.2013.847132.

\begin{tabular}{lll}
\hline 3 & $\begin{array}{l}\text { Don't Know So } \\
\text { Don't Love }\end{array}$ & Ny. Widya Suwarna \\
\hline 4 & $\begin{array}{l}\text { Sandal's for } \\
\text { Mona }\end{array}$ & Ny. Widya Suwarna \\
\hline 5 & $\begin{array}{l}\text { Return of the } \\
\text { Newsreader }\end{array}$ & Ny. Widya Suwarna \\
\hline 6 & House Number 6 & Dwi Pujiastuti \\
\hline 7 & Brass Day & Lena D. \\
\hline 8 & $\begin{array}{l}\text { The Clever Pino } \\
\text { Ny. Widya Suwarna }\end{array}$ \\
\hline 9 & $\begin{array}{l}\text { The Secret of } \\
\text { the Secret } \\
\text { Cabinet }\end{array}$ & Ny. Widya Suwarna \\
\hline 10 & $\begin{array}{l}\text { When the Water } \\
\text { Pump Broke }\end{array}$ & Ny. Widya Suwarna \\
\hline
\end{tabular}

\section{Results}

Based on the results of data analysis conducted on ten short stories from Bobo magazine, it was found that there were indicators of self-concept in each story. In line with Burns' idea, that self-concept in the story is also described through self-image based on the character's personal views, the views of other characters, and the character's wishes/hopes to be like. ${ }^{21}$ In each story, there is more than one indicator of selfconcept. Most self-concept findings are found in the stories "House Number 6" and "The Disappointed Little Author," with five self-concept indicators. Meanwhile, the least self-concept findings were found in the story "Sandal's for Mona" with only two indicators. Indicators of self-concept in children's stories in Bobo magazine are presented in full in the following table.

\footnotetext{
${ }^{21}$ Robert B. Burns, Konsep Diri: Teori, Pengukuran, Perkembangan dan Perilaku, trans. Eddy (Bandung: Arcan, 1993), vi.
} 
Table 2.

Finding Indicators of Self-Concept in Children's Stories in Bobo Magazine

\begin{tabular}{|c|c|c|c|c|c|c|c|c|c|}
\hline \multirow[t]{2}{*}{ No } & \multirow[t]{2}{*}{ Title } & \multicolumn{3}{|c|}{ Internal Dimension } & \multicolumn{5}{|c|}{ External Dimension } \\
\hline & & $\begin{array}{l}\text { Personal } \\
\text { Identity }\end{array}$ & $\begin{array}{l}\text { Self } \\
\text { Behavior }\end{array}$ & Self-Judging & Physical & Moral & Personal & Family & Social \\
\hline 1. & Circus & Good girl. & - & - & - & - & $\begin{array}{l}\text { Willing to } \\
\text { sacrifice to } \\
\text { help } \\
\text { others. }\end{array}$ & $\begin{array}{l}\text { Loving } \\
\text { sister. }\end{array}$ & - \\
\hline 2. & $\begin{array}{l}\text { The } \\
\text { Disappointed } \\
\text { Little Author }\end{array}$ & $\begin{array}{l}\text { Want to be a } \\
\text { writer. }\end{array}$ & $\begin{array}{l}\text { Less } \\
\text { helpful. }\end{array}$ & $\begin{array}{l}\text { Feeling lousy } \\
\text { and } \\
\text { incompetent. }\end{array}$ & $\begin{array}{l}\text { Always try } \\
\text { and work } \\
\text { hard. }\end{array}$ & - & $\begin{array}{l}\text { Get a new } \\
\text { spirit. }\end{array}$ & - & - \\
\hline 3. & $\begin{array}{l}\text { Don't Know } \\
\text { So Don't Love }\end{array}$ & Bookworm. & - & Feeling stupid. & $\begin{array}{l}\text { Always } \\
\text { study. }\end{array}$ & - & - & - & $\begin{array}{l}\text { Accept } \\
\text { difference } \\
\text { s friends. }\end{array}$ \\
\hline 5. & $\begin{array}{l}\text { Return of the } \\
\text { Newsreader }\end{array}$ & $\begin{array}{l}\text { I want to be } \\
\text { a television } \\
\text { announcer. }\end{array}$ & - & $\begin{array}{l}\text { Feeling } \\
\text { ashamed of } \\
\text { envy. }\end{array}$ & - & - & - & $\begin{array}{l}\text { Feeling } \\
\text { sorry for } \\
\text { Grandpa. }\end{array}$ & - \\
\hline 6. & $\begin{array}{l}\text { House } \\
\text { Number } 6\end{array}$ & Weird kid. & $\begin{array}{l}\text { Always } \\
\text { curious } \\
\text { and } \\
\text { ignorant. }\end{array}$ & - & $\begin{array}{l}\text { Boys must } \\
\text { be strong, } \\
\text { not } \\
\text { crybaby. }\end{array}$ & $\begin{array}{l}\text { Promise } \\
\text { not to be } \\
\text { naughty } \\
\text { again. }\end{array}$ & - & - & $\begin{array}{l}\text { Dare to } \\
\text { apologize. }\end{array}$ \\
\hline 7. & Brass Day & Good girl. & $\begin{array}{l}\text { Obedient } \\
\text { and } \\
\text { helpful. }\end{array}$ & - & - & - & - & $\begin{array}{l}\text { Do not } \\
\text { forget the } \\
\text { obligation } \\
\text { to help } \\
\text { Mother. }\end{array}$ & - \\
\hline 9. & $\begin{array}{l}\text { The Secret of } \\
\text { the Secret } \\
\text { Cabinet }\end{array}$ & $\begin{array}{l}\text { Wants to be } \\
\text { a journalist. }\end{array}$ & $\begin{array}{l}\text { Smart and } \\
\text { always } \\
\text { trying. }\end{array}$ & - & - & - & - & - & $\begin{array}{l}\text { Sacrifice } \\
\text { for } \\
\text { friendship. }\end{array}$ \\
\hline 10. & $\begin{array}{l}\text { When the } \\
\text { Water Pump } \\
\text { Broke }\end{array}$ & $\begin{array}{l}\text { Grandma is } \\
\text { attached. }\end{array}$ & $\begin{array}{l}\text { Don't like } \\
\text { being } \\
\text { asked. }\end{array}$ & - & - & - & $\begin{array}{l}\text { Able to } \\
\text { work } \\
\text { together } \\
\text { with } \\
\text { others. }\end{array}$ & - & - \\
\hline
\end{tabular}

The representation of self-concept in the story is classified based on internal dimensions and external dimensions according to Fitts' idea, where each dimension has its own indicators, including the following.

\section{Internal Dimension}

The internal dimension is the overall understanding of the person as a unique entity, including indicators of the identity attached to him, his perception of behavior, and his judgement of the behavior.

\section{a. Personal Identity}

Personal identity is a label used to describe a person, which comes from other people and not himself. There are 9 out of 10 stories that mention indicators of self-concept in the form of identity. As seen in the sentence "You are a good 
girl!" 'and' "Yes, Yuni's sister is a good girl!" her two younger siblings shouted ' (in the Circus). The quotes from the sentences show an indicator of selfconcept in the form of identity that comes from the views of other characters by labeling a good child.

Other quotes that show indicators of self-concept in the form of Identity are as follow:

'Am I not good at writing, sir? Actually, I want to be a writer!" asked Lala' (quoted from The Disappointed Little Author)

"But, apparently, Mirna's mother told Mirna to invite Eni, the bookworm, to join her." (quoted from Don't Know so Don't Love)

"....Actually, I aspire to be a television announcer," said Riani while handing over an invitation card.' (quoted from The Return of the Newsreader)

"'Ehm, let's prank that weird kid!" said Dito.' (quoted from House Number 6)

"You are a good girl, Sri," Ardani praised.' (quoted from Brass Day)

"Good, Pino. One day you will be the leader..." (quoted from The Clever Pino)

"Of course, Grandmother. Because Bayu wants to be a journalist. So, $i$ need to find out interesting things..."' (quoted from The Secret of the Secret Cabinet)

"The loudest one is Rosa, who is usually called "Grandmother Attached" because the most chatty." (quoted from When the Water Pump Broke).

\section{b. Self-behavior}

Self behavior is a label used to a person's perception of his behavior or the way he acts. There are 5 out of 10 stories that mention indicators of self-concept in the form of behavior. As can be seen in the sentences below.

"She feels that herself is not helping others. All this time she likes to be lazy when her mother invites her to visit sick people." (quoted from the Disappointed Little Author)

"However, a few days later, my friends and I did this reconnaissance again. Curiosity kept us from being deterred." and "Hey, let's prank that weird kid!" said Dito.' (quoted from House Number 6)

"Every holiday she never really took a vacation. Her mother's job of receiving orders for Balinese canang and cakes for offerings keeps them busy for the holidays." (quoted from Brass Day)

"...You're smart, just like your greatgrandfather!' praised Grandmother." and "... Therefore try to do good every day," said Grandmother, then locked the door of her carving cupboard.' (quoted from The Secret of the Secret Cabinet)

'"... I am a maid?, I have to carry water. No! Now I want to take a bath as much as I want..."' (quoted from When the Water Pump Broke).

\section{c. Self Judgement}

Self Judgement is a label used to describe a person's perception related to the acceptance or rejection of his identity and behavior. There are 4 out of 10 stories that mention indicators of selfconcept in the form of behavior. As can be seen in the sentences below.

'"I really didn't succeed. Why bother making up?" thought Lala. And she decided to stop keeping a diary.' (quoted from Disappointed Little Author)

"I just watched and felt so stupid. During this time, all the housework was done by Mother and Mbok Sinah." 
(quoted from Don't Know so Don't Love)

"Dora was embarrassed too. Riani was always friendly and even said that Dora's family had been good to her. In fact, Dora has feelings of envy." (quoted from The Return of the Newsreader)

and "... You can read the situation and take appropriate action. I'm proud of you," said Pino's father." (quoted from the Clever Pino)

\section{External Dimension}

The external dimension relates to the judgement of individuals through their social relationships and activities, which are related to indicators such as physical, moral, personal, family, and social.

\section{a. Physical self-concept}

It is related to health, appearance, physical skills, and gender. There are 3 sentences out of 10 stories that mention indicators of physical self-concept. As shown in the sentences.

"Talent is only 10 percent, Lala. The 90 percent is effort and hard work...." Mr. Awang is encouraging." (quoted from the story of the Disappointed Little Author)

'"Oh, not really. I'm still learning how to cook, with Mama. We can do anything if we want to learn!" said Eni.' (quoted from Don't Know So Don't Love)

The two fragments of the sentences above relate to one's skills; and

"It's okay, you'll get better soon, really! Boys have to be strong, don't be a crybaby!" entertain Mr. Umang friendly. (quoted from House Number 6)

This part of the sentence relates to gender.

\section{b. Moral self-concept}

It is related to a person's ability to control his own behavior. There are 2 out of 10 stories that mention indicators of moral self-concept. As seen in the snippet of the sentences.

"Thank you Grandma, thank you! This is a real surprise! Right, yes, Grandma! If I want anything, I have to be patient." (quoted from Sandal's for Mona)

'"Gosh, sir! My goodness! I promise I won't be naughty again, sir!" I screamed hysterically, I burst into tears.' (quoted from House Number 6)

\section{c. Personal self-concept}

It is related to the ability to adapt and have good relationships with others. There are 3 out of 10 stories that mention indicators of personal self-concept. As seen in the fragment of the sentences below.

'"No need, ma'am!" reject Yuni gently. "I'm going to Grandma ljah's house. She's sick."' (quoted from Circus)

'All the way home the old mother's words kept ringing in Lala's ears and she got a new spirit.' (quoted from the Disappointed Little Author)

'"Edi and I will ask Mr. Dudi for water. We both will carry and fill the tub until it's full again after we bathe as much as we can!" Iwan made an announcement." (quoted from When the Water Pump Broken)

\section{d. Family self-concept}

It is related to a person's view of his existence in his family and relatives. There are 4 out of 10 stories that mention indicators of family self-concept. As shown in the snippets of the sentences. 
"Finally, when that day comes, Yuni dresses her two sisters as neatly as possible;" "But, I want to take care of Grandma ljah;" "The important thing is that my younger siblings can watch." (quoted from Circus)

"Dora felt all wrong. If she didn't read the news to Grandpa, she also felt guilty. As a grandson, he doesn't want to help his grandfather?" (quoted from The Return of the Newsreader)

"Of course Sri couldn't bear to leave her mother working alone;", "... She can go on vacation to a friend's house and at the same time don't forget to help her mother." (quoted from Brass Day)

"Every time an oil tanker comes, Pino's father buys two jerry cans. Today it is Pino who bought it, because his father and mother are at the village head's house." (quoted from the Clever Pino)

\section{e. Social self-concept}

It is related to the size of a person's views related to his relationship with peers. There are 4 out of 10 stories that mention indicators of social self-concept. As seen in the passage of the sentences below.

"I will also accept everyone as they are. Eni doesn't need to be fussy like the four of us." (quoted from Don't Know So Don't Love)

"'Aling said, "Put on my sandals. Your feet will hurt if you don't wear sandals!" So, Mona went home wearing Aling's sandals." (quoted from Sandal's for Mona)

'"Forgive my mistake, please," I said softly as I reached out to Hurricane. The storm greeted him with a genuine smile.' (quoted from House Number 6)

"My great-grandmother has taught me something valuable in my life. That friendship requires sacrifice and care?" (quoted from The Secret of the Secret Cabinet).
In general, the dominant indicator of children's self-concept in the ten short stories analyzed by Bobo magazine is self-identity. This is because self-identity is much easier to identify. After all, it relates to the character's desire to become what he or she is and the labels that other characters attached to the characters in the story. Tsakiris notes that it seems to be grounded in explicit and conceptual representations such as someone's memories, personality traits, beliefs, and attitudes. ${ }^{22}$

Meanwhile, other indicators are only explained indirectly through monologue, dialogue, or character behavior. Each reader will understand the self-concept differently, and this self-concept will continue to develop and may even change over time. As Burns explained, selfconcept is still a hypothetical idea and is considered a dynamic process. ${ }^{23}$ It would also be developed on a longer timescale typical of long-term developmental processes. ${ }^{24}$ However, readers, especially children, can still understand the concept of self through interactions between characters in the story. As Millward \&

\footnotetext{
${ }^{22}$ Manos Tsakiris, "Self and Brain," in International Encyclopedia of the Social \& Behavioral Sciences (Second Edition), ed. James D. Wright (Oxford: Elsevier, 2015), 419-23, https://doi.org/10.1016/B978-0-08-097086-8.560346.

23 Burns, Konsep Diri: Teori, Pengukuran, Perkembangan dan Perilaku, 84.

24 Anna Lichtwarck-Aschoff et al., "Time and Identity: A Framework for Research and Theory Formation," Developmental Review 28, no. 3 (2008): 370-400, https://doi.org/10.1016/j.dr.2008.04.001.
} 
Kelly mentions that the concept of identity evolves out of social interaction. ${ }^{25}$

The character's identity being told will bring up a new imagination for the reader to understand his own identity. Likewise, children will imitate the characters' behavior and provide values in the form of acceptance or rejection of the behavior that appears within themselves.

The self-behavior indicators depicted in Bobo magazine's five children's stories contain two good behaviors, such as always helping mothers and trying to do good, as well as three destructive behaviors, such as being unhelpful, ignorant, and not liking to be told. As explained by Nurgiyantoro, such a story does not mean a story without morals but rather a description of behavior that can help children to identify themselves. ${ }^{26}$ As mentioned by Farahiba, that children's literature is not a teaching about ethics and morals, even though it contains idealized moral and ethical behavior as modeled by the story characters, and also children's literature is not a lesson in religion or character, even though it contains the principles of life and religious behavior as portrayed by the characters in the story. Children's literature is a model of cultured life in action, in the attitudes and behavior of characters. ${ }^{27}$

25 Louise M. Millward and Michael P. Kelly, "Incorporating the Biological: Chronic Illness, Bodies, Selves, and the Material World," in Debating Biology (London: Routledge, 2003).

${ }^{26}$ Nurgiyantoro, "Sastra Anak," 2.

${ }^{27}$ Ayyubi Subhi Farahiba, "Eksistensi Sastra Anak dalam Pembentukan Karakter pada Tingkat Pendidikan Dasar," Waskita: Jurnal Pendidikan
Therefore, with the present selfbehavior of a character that describes a child who is not good, it will be a picture of the reader to understand himself, whether it is similar to the character in the story or vice versa. Furthermore, the descriptions of self-judgment indicators contained in the four stories of Bobo magazine contain judgments that reject their behavior, such as feeling unsuccessful, stupid, and ashamed. As well as a judgment that is acceptance of the behavior carried out, namely feeling proud.

In addition, in the external dimension, the description of indicators of physical self-concept is found in three stories related to the skills of the characters and their gender. Furthermore, the description of the moral self-concept in this story relates to the character's ability to control his behavior, such as being patient if he wants something and not bullying others. The next indicator of personal self-concept in this story is related to good relations between characters, which is described by characters' behavior who like to help, cooperate, and get new enthusiasm after meeting other characters. Then, the indicators of family self-concept in this story are described by the character's relationship with family members such as younger siblings, fathers, mothers, and grandfathers. Finally, the indicators of social self-concept in this story are depicted through the character's relationship with his peers who help each other.

Nilai dan Pembangunan Karakter 1, no. 1 (2019): 47-59,

https://doi.org/10.21776/ub.waskita.2017.001.01.3. 
In the ten children's stories of Bobo magazine analyzed, every life problem experienced by the character will certainly form awareness of self-concept, including the ability to make decisions, always help parents, love every family member, and always try and be passionate about achieving something. This self-concept indicator is also related to the views or perceptions of other characters, which implicitly provide a picture of the expected self. This confirms that the idealization of children's self-concepts as readers can be understood through the analysis of selfconcept indicators represented in children's stories. For this reason, the selfconcept analysis in this collection of children's stories from Bobo magazine was carried out.

\section{Conclusion}

The self-concept in this study is a picture of self from the character formed by the character's personal awareness, view of himself, and the character's desire/expectation to actualize himself. Self-Identity becomes the dominant indicator of self-concept that appears in the children's story of Bobo Magazine, then followed by indicators of selfbehavior, self-judgment, family selfconcept, social self-concept, physical selfconcept, personal self-concept, and moral self-concept. Each story does not contain all indicators in the internal dimension or external dimension. However, the children's stories in Bobo magazine have included self-concepts in the stories they contain. This shows the author's concern as an adult to provide a reading that is able to provide understanding to construct children's self-concepts. So, that children can gain knowledge about themselves, and these indicators will indirectly serve as an illustration to reconstruct attitudes readers, especially children. Moreover, it is also hoped that the results of this study can be the starting gate for authors to provide children's stories who have a selfconcept.

Therefore, this research is expected to be a reference for further researchers to be able to uncover and describe more representations of self-concepts contained in children's stories in Indonesia. At the same time, this research is also expected to be a starting point for storytellers, especially children's story writers, to be more aware of the importance of selfconcept and provide it explicitly in the stories they write.

\section{References}

Agustiani, Hendriati. Psikologi Perkembangan. Bandung: PT. Refika Aditama, 2009.

Apriliya, Seni, Dadang Sunendar, Yeti Mulyati, and Sumiyadi. "Social Identity in Indonesian Children's Literature: Materials of Self-Literacy for Elementary Students," 548-50. Atlantis 2018. https://doi.org/10.2991/amca18.2018.152.

Bailey, Joseph A. "Self-Image, SelfConcept, and Self-Identity Revisited." Journal of the National Medical Association 95, no. 5 (2003): 383-86.

Burns, Robert B. Konsep Diri: Teori, Pengukuran, Perkembangan dan Perilaku. Translated by Eddy. Bandung: Arcan, 1993. 
Farahiba, Ayyubi Subhi. "Eksistensi Sastra Anak dalam Pembentukan Karakter pada Tingkat Pendidikan Dasar." Waskita: Jurnal Pendidikan Nilai dan Pembangunan Karakter 1, no. 1 (2019): 47-59. https://doi.org/10.21776/ub.waskita. 2017.001.01.3.

Fitts, William H., and W. Louis Warren. Tennessee Self-Concept Scale. 2nd ed. California: Western Psychological Services, 1996.

Hayati, Yenni. "The Use of Foreign Languages in Children Literature in Indonesia." Humanus 15, no. 2 (2016): 226-35. https://doi.org/10.24036/jh.v15i2.651 1.

Hurlock, Elizabeth Bergner. Child Development. 5th ed. New York: McGraw-Hill, 1978.

Kurniawan, Heru kurniawan, Herman J. Waluyo, Sarwiji Suwandi, and Budhi Setiawan. "Kepribadian Moral Ideal Anak dalam Cerita Anak pada Majalah Bobo dan Harian Kompas." Lingua 14, no. 2 (2018): 226-40.

Lichtwarck-Aschoff, Anna, Paul van geert, Harke Bosma, and E. Kunnen. "Time and Identity: A Framework for Research and Theory Formation." Developmental Review 28, no. 3 (2008): 370-400. https://doi.org/10.1016/j.dr.2008.04. 001.

Millward, Louise M., and Michael P. Kelly. "Incorporating the Biological: Chronic Illness, Bodies, Selves, and the Material World." In Debating Biology. London: Routledge, 2003.

Minderop, Albertine. Psikologi Sastra: Karya Sastra, Metode, Teori, dan Contoh Kasus. Jakarta: Yayasan Pustaka Obor Indonesia, 2010.

Moleong, Lexy J. Metodologi Penelitian Kualitatif. Bandung: Remaja Rosdakarya, 2009.

Nirwana. "Konsep Diri, Pola Asuh Orang Tua Demokratis dan Kepercayaan
Diri Siswa." Persona: Jurnal Psikologi Indonesia 2, no. 2 (2013): 153-61.

https://doi.org/10.30996/persona.v2i 2.103.

Nurgiyantoro, Burhan. "Sastra Anak: Persoalan Genre." Humaniora 16, no. 2 (2012): 107-22. https://doi.org/10.22146/jh.811.

Richter, Tobias, Markus Appel, and Frank Calio. "Stories Can Influence the Self-Concept." Social Influence 9, no. 3 (2014): 172-88. https://doi.org/10.1080/15534510.20 13.799099 .

Saptawuryandari, Nurweni. "Cerita Pendek Anak dalam Majalah Bobo Tahun 1980-an sebagai Bacaan Pendidikan Karakter." ATAVISME 17, no. 2 (2014): 254-63. https://doi.org/10.24257/atavisme.v1 7i2.14.254-263.

Sarumpaet, Riris K. Toha. Pedoman Penelitian Sastra Anak. Jakarta: Yayasan Pustaka Obor, 2010.

Schumm, Jeanne Shay, Jill LewisSpector, Debra Price, and Kristen Doorn. "A Content Analysis of College Reading Association/Association of Literacy Educators and Researchers Teacher Education Publications: Past, Present, and Future." Literacy Research and Instruction 53, no. 3 (2014): 225-44. https://doi.org/10.1080/19388071.20 13.847132 .

Silva, Wellington Amancio da. "Literature Children - Child as Protagonist." International Journal of Elementary Education 3, no. 3 (2014): 54. https://doi.org/10.11648/j.ijeedu.201 40303.11.

Tsakiris, Manos. "Self and Brain." In International Encyclopedia of the Social \& Behavioral Sciences (Second Edition), edited by James D. Wright, 419-23. Oxford: Elsevier, 2015. https://doi.org/10.1016/B9780-08-097086-8.56034-6. 
Uszyńska-Jarmoc, Janina. "The Conception of Self in Children's Narratives." Early Child Development and Care 174, no. 1 (2004): 81-97. https://doi.org/10.1080/0300443032 000153507.
Wagener, Elaine $\mathrm{H}$. "Does Literature Affect Self-Concept?" Peabody Journal of Education 53, no. 4 (1976): 299-302. https://www.jstor.org/stable/1492283. 